\title{
Water Quality from Mangrove Forest: The King's Royally Initiated Laem Phak Bia Environmental Research and Development Project, Phetchaburi Province, Thailand
}

\author{
Orathai Jitthaisong ${ }^{1}$, Pricha Dhanmanonda ${ }^{2}$, Kasem Chunkao $^{1} \&$ Sakhan Teejuntuk $^{2}$ \\ ${ }^{1}$ College of Environment, Kasetsart University, Bangkok 10900, Thailand \\ ${ }^{2}$ Faculty of Forestry, Kasetsart University, Bangkok 10900, Thailand \\ Correspondence: Orathai Jitthaisong, College of Environment, Kasetsart University, Bangkok 10900, Thailand. \\ Tel: 66-2-892-765-905. E-mail: Orathai.jitt@hotmail.com
}

\author{
Received: May 28, $2012 \quad$ Accepted: July 2, $2012 \quad$ Online Published: July 8, 2012 \\ doi:10.5539/mas.v6n8p1 \\ URL: http://dx.doi.org/10.5539/mas.v6n8p1
}

The research is financed by the King's Royally Initiated Laem Phak Bia Environmental Research and Development Project

\begin{abstract}
The study was aimed to study water quality treated by mangrove forest. This study has been conducted at the mangrove forest site of the King's Royally Initiated Laem Phak Bia Environmental Research and Development Project (the Royal LERD Project), Ban Laem District, Phetchaburi Province, Thailand. The study site, where Avicennia marina is dominant plant, is divided into in 3 areas; (A) the tideland area between constructed pond and mangrove forest, 200 meters from outlet (B) area of mangrove forest, distance 201 to 900 meters from outlet and (C) sea area, started from 901 meters from outlet. Six parameters were investigated; including temperature, $\mathrm{pH}$, dissolved oxygen (DO), phosphate, nitrate, and ammonia. The results showed that water quality from mangrove forest met the effluent standards for coastal aquaculture (Ministry of Natural Resources and Environment, 2004). Mangrove forest can be able to improve water quality by increasing DO by $32.39 \%$, while reducing phosphate, ammonia, and nitrate by $88.23 \%, 73.77 \%$, and $64.28 \%$ respectively. It can be used as an additional natural system to increase the efficiency of man-made wastewater treatment system.
\end{abstract}

Keywords: water quality, mangrove forest, Thailand

\section{Introduction}

In recent years, a lot of mangrove forests have consecutively been depleted along with muddy beach in the Gulf of Thailand from Bangkok to Phetchaburi province, approximately 150 kilometers, due to development of infrastructure, industries, human settlements, and tourism facilitation. Besides, polluted water from the main rivers (Chao Phraya, Mae Klong, Tachin, Phetchaburi, and Bang Pakong rivers) were accused as another causes of reducing coverage areas of mangrove forest in Western coastal zones. Such a situation would not be ignored since marine animals such as catching fishes, crabs, crams, shells, shrimps, pawn, crawfishes, and clay fishes are decreasing. Previous researches reported that healthy and wealthy of mangrove forest should be enhance the natural mechanism to recover the fruitfulness of marine animals as well as wastewater treatment systems. Unfortunately, the practical performance has hardly existed, especially mangrove reforestation, existing dense forest evacuation protection, and monitoring measures from concerned government offices. In order to recover the mangrove forest along the Bangkok-Phetchaburi muddy beach, King Bhumiphol of Thailand has initiated the project to handle wastewater from Phetchaburi Municipal by utilizing the nature-by-nature process to rehabilitate the disturbed mangrove forest productivity by treated wastewater along with high nutrient concentration. In other words, H.M. the King really needs to prove that the nature-by-nature process has capability to produce inorganic nutrients, as converted from waste organic matter in municipal wastewater, for aquatic plants and animal growth which are the indicators of mangrove forest productivity.

In present days, municipality wastewater directly is discharged to The King's Royally Initiated Laem Phak Bia Environmental Research and Developmental Project, then, flows through mangrove forest and the sea 
respectively. However, there is no research which indicates the changing of water quality into mangrove forest, remaining in the forest, and the final quality of water flowing out to the sea.

The objective of this research aims to study on water quality which treated from a constructed pond system, flowing into and out of the mangrove forest in order to develop the efficiency of nature-by-nature municipal wastewater treatment.

\section{Materials and Method}

\subsection{Study Area}

This study was conducted at the Experimental Site of the Royal LERD Project which was established since 1991. The size of the Project is approximately 7,500 hectares plus 300 meter-width natural mangrove forest along the muddy beach of the Phetchaburi river mouth as shown in Figure 1. It was told that before 1991, there was shrimp farming. Due to environmental damages, the barrens shrimp farmland was abandon. Fortunately, the Project activities could be able to revive the areas because of gradual mud settling as a result of mangrove tree succession. The location of the Project is located in Laem Phak Bia sub-district, Ban Laem District, Phetchaburi Province, in the south of the central part of Thailand.

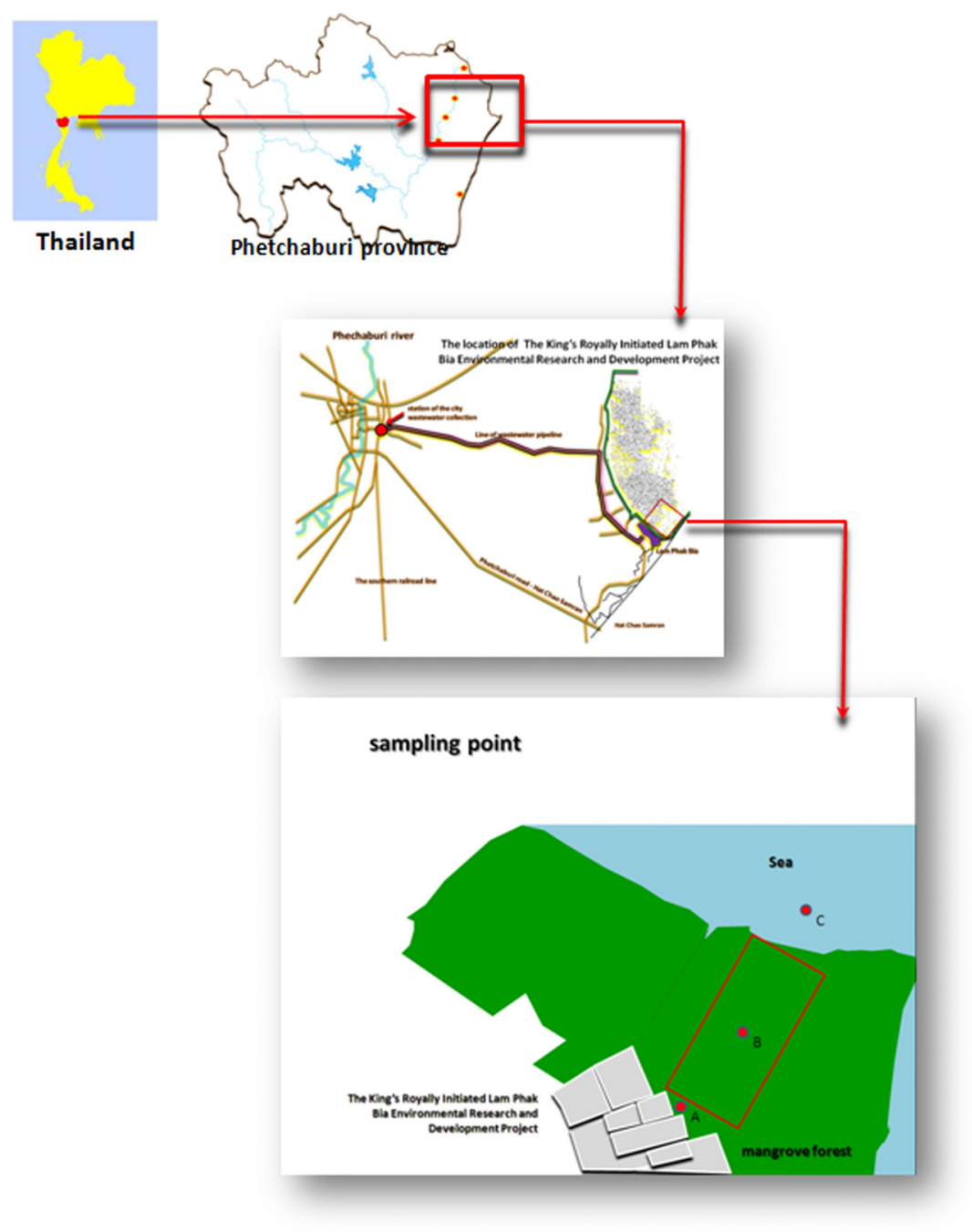

Figure 1. Study site in the Royal LERD

The study site is situated in mangrove forest between constructed pond which receives wastewater from Phetchaburi's municipality, and sea. The forest area is approximately 160 hectares where Avicennia marina is mono-dominant plant, tree density is $3,645.83$ stems/hectare, average height is 6.17 meters, diameter at breast height (DBH) is 6.27 centimeters, biomass 44.03 tons/hectare and sapling density is $3,172.79$ stems/hectare. 
Flow rate of treated wastewater from constructed pond into mangrove forest is approximately $3,600 \mathrm{~m}^{3} /$ day.

\subsection{Experimental Design}

The trial set up in the mangrove forest and the sea were divided into 3 areas viz. (A) the tideland area between the constructed pond and the mangrove forest, 200 meters from outlet; (B) area of mangrove forest, distance 201 to 900 meters from outlet; and (C) sea area, started from 901 meters from outlet as shown in Figure 2.

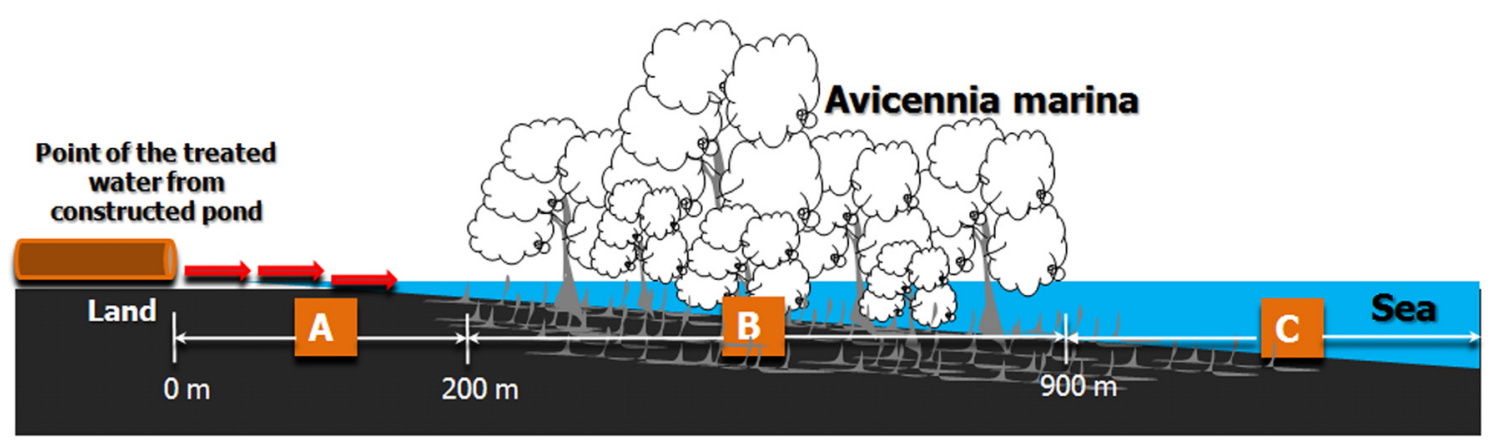

Figure 2. Sampling collected point

\subsection{Collection and Analyses of Water Samples}

Collection of water samples was in the period of October 2009 to September 2010, on the highest tide of the day in each month. About $2,000 \mathrm{~mL}$ of effluent samples was collected with 2 bottles of $1,000 \mathrm{~mL}$ bottle at 30 centimeters depth from sea level, 3 replications of 3 points in mangrove forest to be representative of,viz. (a) effluent water from constructed pond treatment, 100 meters from outlet; (b) effluent in the mangrove forest, 600 meters from the outlet; and (c) effluent out of the mangrove forest-1,250 meters from outlet (Figure 2). Six parameters i.e. temperature, $\mathrm{pH}$, dissolved oxygen (DO), phosphate, nitrate and ammonia were measured against Effluent Standard for Coastal Aquaculture (Ministry of Natural Resources and Environment, 2004).

The collected water samples were tested according to the standard methods for the Examination of Water and Wastewater (APHA, AWWA, \& WEF, 2005), Practical Handbook of Seawater Analysis (Stickland \& Parsons, 1977), Methods of Seawater Analysis (Koroleff, 1999), Determination of Ammonia in Estuary (Sasaki \& Sawada, 2006), Methods of Seawater Analysis (Grasshoff, 1976) and Manual for Water and Wastewater Examination of Environmental Engineering Association of Thailand and WEF as shown in Table 1.

Table 1. Material and method

\begin{tabular}{cc}
\hline Parameters & Material and Method \\
\hline Temperature $\left({ }^{\circ} \mathrm{C}\right)$ & Thermometer \\
$\mathrm{pH}$ & $\mathrm{pH}$ Meter \\
Dissolved Oxygen $(\mathrm{mg} / \mathrm{L})$ & DO Meter \\
Phosphate $(\mathrm{mg} / \mathrm{L})$ & Ascorbic Acid Method \\
Nitrate $(\mathrm{mg} / \mathrm{L})$ & Cadmium Reduction Method \\
Ammonia $(\mathrm{mg} / \mathrm{L})$ & Phenate Method \\
\hline
\end{tabular}

\subsection{Statistical Analysis}

Mean values of each point, 12 months, of water sampling were calculated and then compared with Effluent Standards for Coastal Aquaculture (Ministry of Natural Resources and Environment, 2004) as shown in Table 2. 


\section{Results and Discussion}

\subsection{Temperature}

The temperature of water at point $\mathrm{B}$ and $\mathrm{C}\left(26.99^{\circ} \mathrm{C}\right.$ and $\left.27.41^{\circ} \mathrm{C}\right)$ were lower than temperature at point $\mathrm{A}$ $\left(27.69^{\circ} \mathrm{C}\right)$. The temperature of each point was below the water quality standards for coastal area $\left(28.0^{\circ} \mathrm{C}\right)$ as shown in Table 2 and Figure 3.

Table 2. Temperature, $\mathrm{pH}$, dissolved oxygen, phosphate, nitrate, ammonia compared with standard values

\begin{tabular}{ccccc}
\hline Parameters & Standard & A & B & C \\
\hline Temperature $\left({ }^{\circ} \mathrm{C}\right)$ & Less than 28 & 27.68 & 26.99 & 27.41 \\
$\mathrm{pH}$ & $7.0-8.5$ & 8.50 & 8.04 & 8.09 \\
Dissolved Oxygen $(\mathrm{mg} / \mathrm{L})$ & More than $4 \mathrm{mg} / \mathrm{L}$ & 4.60 & 6.19 & 6.09 \\
Phosphate $(\mathrm{mg} / \mathrm{L})$ & Less than $0.045 \mathrm{mg} / \mathrm{L}$ & 0.34 & 0.08 & 0.04 \\
Nitrate $(\mathrm{mg} / \mathrm{L})$ & Less than $0.06 \mathrm{mg} / \mathrm{L}$ & 0.14 & 0.05 & 0.05 \\
Ammonia $(\mathrm{mg} / \mathrm{L})$ & Less than $0.1 \mathrm{mg} / \mathrm{L}$ & 0.305 & 0.09 & 0.08 \\
\hline
\end{tabular}

Remarks: The Standard of Effluent Standard for Coastal Aquaculture from Ministry of Natural Resources and Environment (2004), Thailand.

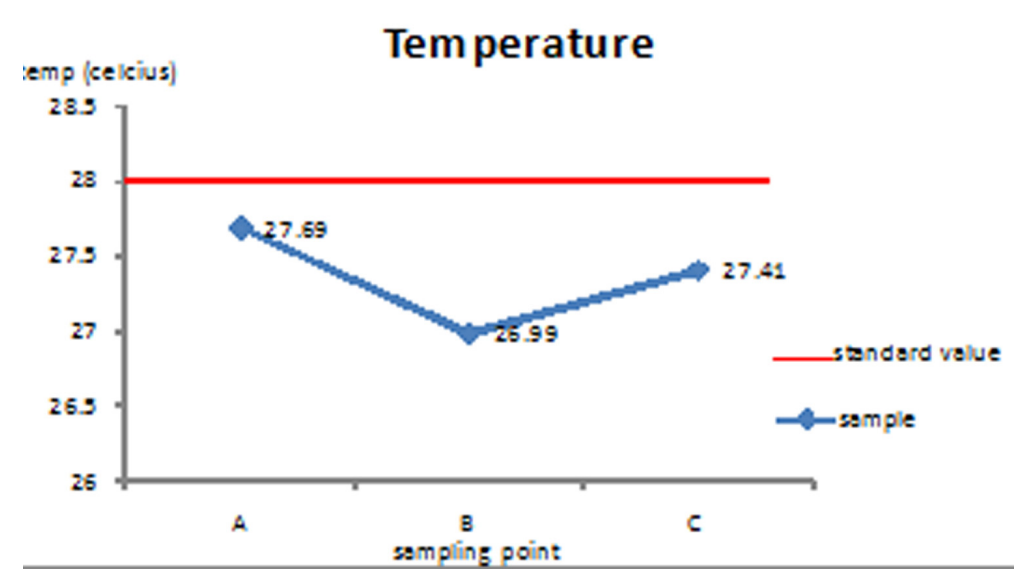

Figure 3. Temperature at sampling point compared with standard value

The temperature of water from the wastewater treatment system (point A) and in the sea (point C) were not significantly different $\left(27.69^{\circ} \mathrm{C}\right.$ and $\left.27.41^{\circ} \mathrm{C}\right)$ because they were both exposed to the sunlight. Therefore, at point $\mathrm{B}$ covered by mangrove forest had less sunlight and lower temperature than point $\mathrm{A}$ and $\mathrm{C}$ which was not covered by mangrove forest. This conformed with Muenphet (2005) who indicated that the temperature of wastewater before flowing into mangrove forest in experiment site $\left(29.63^{\circ} \mathrm{C}-32.27^{\circ} \mathrm{C}\right)$ and out of mangrove forest in experiment site $\left(28.63^{\circ} \mathrm{C}-31.93^{\circ} \mathrm{C}\right)$ was not much different.

\section{$3.2 \mathrm{pH}$}

The $\mathrm{pH}$ at point $\mathrm{B}$ and $\mathrm{C}(8.04$ and 8.09$)$ were lower than $\mathrm{pH}$ at point $\mathrm{A}(8.5)$ and $\mathrm{pH}$ of each point was in the range of water quality standards for coastal area (7.0-8.5) as shown in Table 2 and Figure 4. 


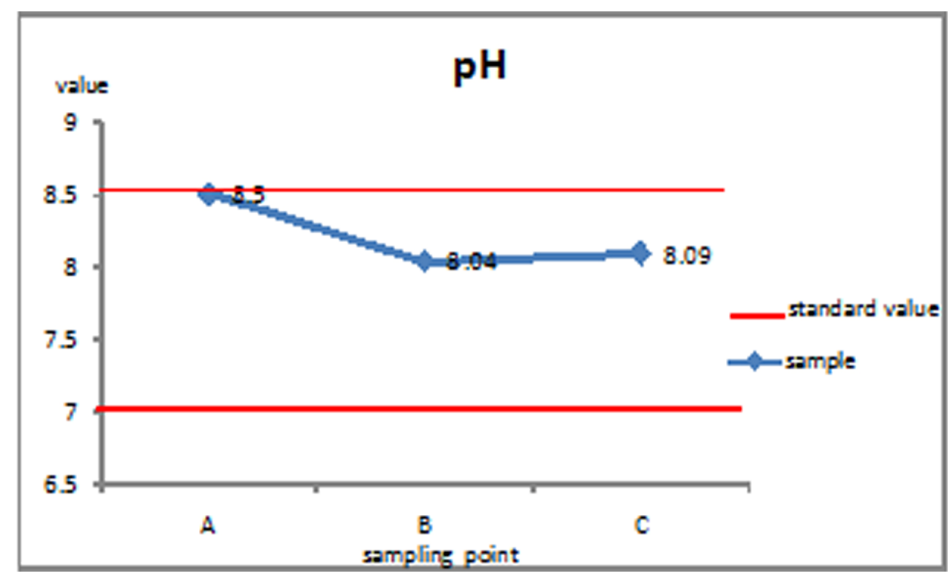

Figure 4. $\mathrm{pH}$ at sampling point compared with standard value

The decreasing of $\mathrm{pH}$ at point $\mathrm{B}$ and $\mathrm{C}$ is caused by fermentation process and organic matter which normally found in the mangrove forest. This organic matter was decomposed by anaerobic bacteria, after this process, low molecular weight of organic acid was produced (Mitsch \& Gosselink, 2000). As the result, pH was decreased. The results of study have conformed with Vorakuldumrongchai (1997) that indicated that the trend show a decrease of $\mathrm{pH}$ in first part (6.8-9.8) middle part (6.5-8.7) and the end part (6.4-8.4) of mangrove forest at Kung Krabane Bay, Chanthaburee Province.

\subsection{Dissolved Oxygen}

The DO at point B and C $(6.19 \mathrm{mg} / \mathrm{L}$ and $6.09 \mathrm{mg} / \mathrm{L})$ were higher than DO at point $\mathrm{A}(4.6 \mathrm{mg} / \mathrm{L})$ and DO of each point was higher than water quality standards for coastal area $(4.0 \mathrm{mg} / \mathrm{L})$ as shown in Table 2 and Figure 5.

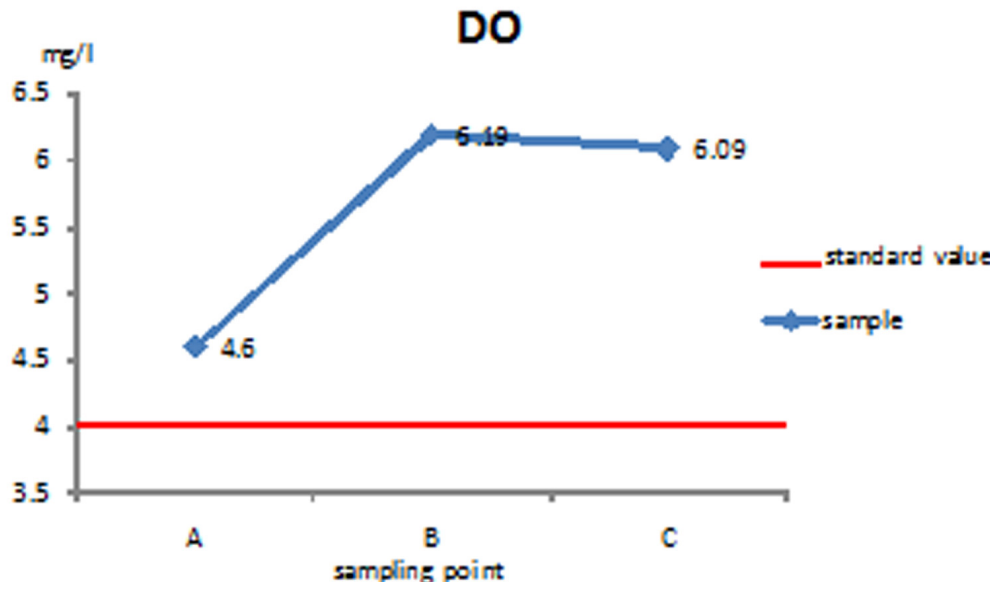

Figure 5. Dissolved Oxygen (DO) at sampling point compared with standard value

The increasing of DO in the mangrove forest was caused by oxygen exchanging at the root system of Avicennia marina which is the mono-dominant plant. Its root system was 100 centimeters depth from soil surface, spread out and has aerial roots (pneumatophores, upward directed root) in which oxygen can passively diffuse (Kathiresan \& Bingham, 2001), and make this oxygen be easily diffused to water (Gill \& Tomlinson, 1977). It is conform to the study of Aksornkoae et al. (2000) which indicated that DO of community wastewater become higher when water was restrained in mangrove forest for 2 weeks and Vorakuldumrongchai (1997) showed that DO values of sea water in the Kung Krabane Bay, Chanthaburee Province which passed through the mangrove area were in the range of $4.0-8.0 \mathrm{mg} / \mathrm{L}$.

\subsection{Phosphate}

Phosphate at point B and C $(0.08 \mathrm{mg} / \mathrm{L}$ and $0.04 \mathrm{mg} / \mathrm{L})$ were significantly lower than those at point A $(0.34 \mathrm{mg} / \mathrm{L})$. At point $\mathrm{B}$, the value was equal to the standard value. Note that values at point $\mathrm{A}$ and $\mathrm{B}$ were higher than water quality standards for coastal area $(0.04 \mathrm{mg} / \mathrm{L})$ as shown in Table 2 and Figure 6. 


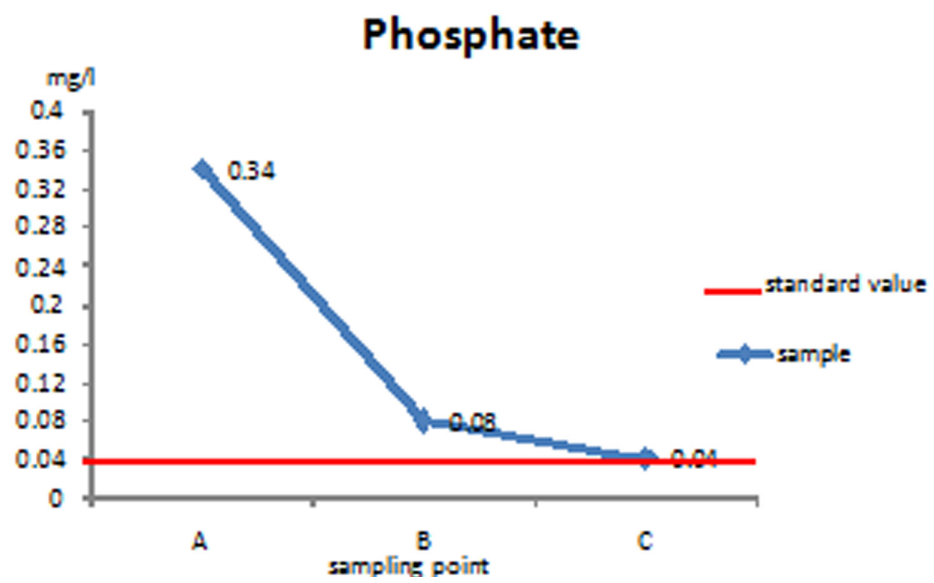

Figure 6. Phosphate intensity at sampling point compared with standard value

The above results agreed with Yang et al. (2008) which indicated that mangrove forest experimental can reduce total phosphorus $60 \%$ and Zhang et al. (2010) who pointed that mangrove wetlands has great potential for the removal of nutrients in coastal areas. The reduction of Phosphate in water was caused by abiotic processes which consisted of 1) sedimentation 2) absorption and precipitation and 3) exchanging process between soil and water column (Reddy \& D'Angelo, 1977). Sedimentation is a process in separating suspended phosphate from seawater while absorption and precipitation are the processes in absorbing phosphate by soil particles; and exchanging between soil and water column is a process in exchanging of dissolved phosphate and particulate phosphate. The result was conform with $\mathrm{Wu}$ et al. (2008) which indicated that mangrove forest experimental can reduce ortho-phosphate by $97 \%$, and total phosphorus by $86.65 \%-91.83 \%$. Zhou et al. (2009) indicated that constructed wetland can reduce total phosphorus from $6 \mathrm{mg} / \mathrm{L}$ to $3 \mathrm{mg} / \mathrm{L}$ in Longdao River and reduce total phosphorus from $7 \mathrm{mg} / \mathrm{L}$ to $0.5 \mathrm{mg} / \mathrm{L}$ in Hangtiancheng, Republic of China. Beside, Avicennia marina is an efficient plant for water treatment due to the study of the efficiency of Avicennia marina for treatment of shrimp farm effluent by Nuengmatcha (2010) shown that Avicennia marina can remove total phosphorus up to $64.04-86.76 \%$.

\subsection{Nitrate}

Nitrate at point $B$ and $C(0.05 \mathrm{mg} / \mathrm{L})$ were lower than water quality standards for coastal area $(0.06 \mathrm{mg} / \mathrm{L})$, and they were lower than Nitrate at point A $(0.14 \mathrm{mg} / \mathrm{L})$ which exceeded standard of water quality standards for coastal area as shown in Table 2 and Figure 7.

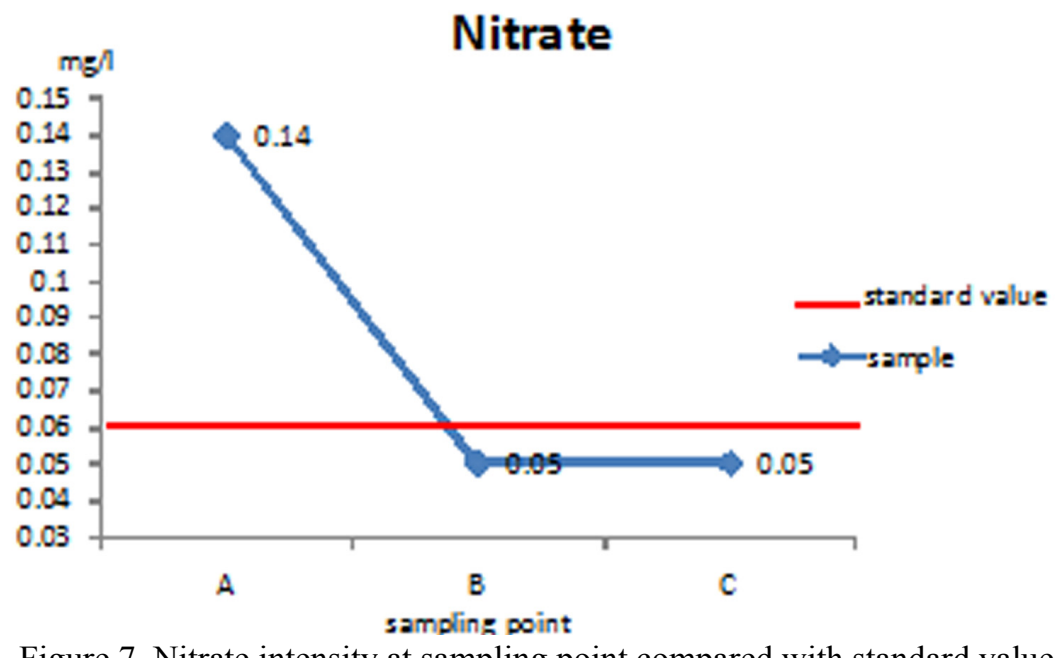

The above results agreed with Yang et al. (2008) and Zhang et al. (2010). The reduction of nitrate was caused by denitrification, unstable nitrogen $\left(\mathrm{NO}_{2}-\mathrm{N}\right.$ and $\left.\mathrm{NO}_{3}-\mathrm{N}\right)$ transforming to $\mathrm{N}_{2}$, and by plant uptake (Jenssen et al., 
1994) for plant growth which Naidoo (2008) indicated that $\mathrm{N}$ and $\mathrm{N}+\mathrm{P}$ treatment, Avicennia marina has plant height, number of leaves, leave chlorophyll content and photo synthesis increased by over control treatment $50 \%$, $330 \%, 30 \%$ and 30\%, respectively. It is conform to $\mathrm{Su}$ et al. (2011) which indicated that mangrove forest can treated aqua wastewater for 5.4-37.7\% and conform to Nuengmatcha (2010) indicated that Avicennia marina can remove Ammonia-Nitrogen and Total Nitrogen for $69.86-87.56 \%$ and $70.32-89.80 \%$, respectively.

\subsection{Ammonia}

Ammonia at point $\mathrm{B}$ and $\mathrm{C}(0.09 \mathrm{mg} / \mathrm{L}$ and $0.08 \mathrm{mg} / \mathrm{L})$ which were lower than standard of water quality standards for coastal area $(0.1 \mathrm{mg} / \mathrm{L})$, was extremely lower than Nitrate at A point $(0.305 \mathrm{mg} / \mathrm{L})$ which is higher than water quality standards for coastal area as shown in Table 2 and Figure 8.

The reduction of ammonia was caused by ammonification changing of amino acid in treated water to ammonia, Denitrification changing of nitrite and nitrate to nitrogen gas (Gray et al., 2000); volatilization, changing of ammonia to ammonia gas and released into the air, and plant and microbial uptake, in from of nitrate (Reddy \& D' Angelo, 1977). It is conform to Wang et al. (2010) which indicated that Sonneratia caseolaris and Kandelia candel can reduce ammonia for $50 \%$.

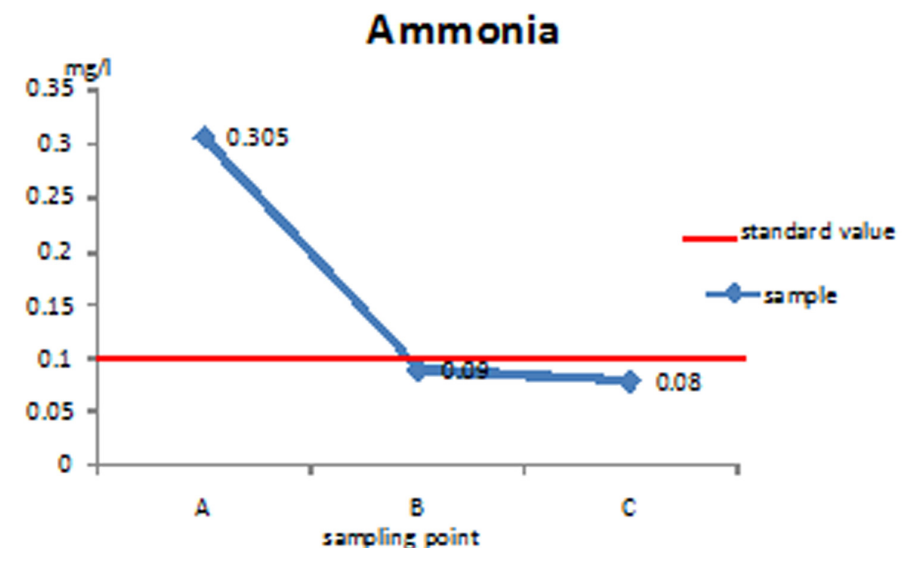

Figure 8. Ammonia intensity at sampling point compared with standard value

\section{Conclusion}

Mangrove forest at the Royal LERD Project at Phetchaburi Province, Thailand which Avicennia marina is mono-dominant plant, tree density is 3,645.83 stems/ha, is the natural system which futher enhance the efficiency of man-made wastewater system. The results of the study show that water quality from mangrove forest is in compliance with water quality standards for coastal area. This natural system increase DO by $32.39 \%$, reduce Phosphate by $88.23 \%$, reduce Nitrate by $64.28 \%$, and reduce Ammonia by $73.77 \%$, respectively.

\section{Acknowledgement}

The first author would like to express sincere gratitude for the Ph.D scholarship from the Office of the Higher Education Commission, Ministry of Education, Thailand.

\section{References}

Aksornkoae, S., Boonyawat, S., \& Singhakan, K. (2000). A Preliminary Study on Application of Mangroves for Polluted Water Treatment at Laem Pak Bia, Petchaburi Province. Documentation of the Conference Science of Waste disposal manipulate and Wastewater management follow the Royal Initiative. The King's Royally Initiated Laem Phak Bia Environmental Research and Development Project. September 24-25, 2000. $7^{\text {th }}$ floor, Wittayapattana Building, Kasetsart University. Chaipattana Foundation.

APHA, AWWA, \& WEF. (2005). Standard Methods for Examination of Water and Wastewater (21 ed.).Washington, D.C.: American Public Health Association (APHA).

Boonsong, K., Patanapolpaiboon, P., \& Piyatiratitivorakul, S. (2000). Usage of mangroves in sewage treatment: Their growth and nutrients status. The Thailand Research Fund, p.73.

Gill, A. M., \& Tomlinson, P. B. (1997). Studies of the Growth of Red Mangrove (Rizophara mangle) 4. Adult Ro Sustem.Biotropica., 9, 145-155. http://dx.doi.org/10.2307/2387877 
Gray, S., Kinross, J., Read, P., \& Marland, A. (2000). The nutrient assimilative capacity of mearl as a substrate in constructed wetland systems for waste treatment. Wat. Res., 34(8), 2183-2190. http://dx.doi.org/10.1016/S0043-1354(99)00414-5

Kadlec, R. H., \& Knight, R. L. (1996). Treatment Wetlands. United State of America: CRC Press.

Kathiresan, K., \& Bingham, B. L. (2001). Biology of Mangrove and Mangrove Ecology. Advances in Marine Biology, 40.

Ministry of Natural Resources and Environment. (2004). Water Quality Standards for Coastal Area. Retrieved from http://www.pcd.go.th/info_serv/en_reg_std_water02.html

Mitsch, W. J., \& Gosseling, J. G. (2000). Wetland ( $3^{\text {rd }}$ ed.). New York: John Wiley \& Sons.

Muenphet, N. (2005). Effect of wastewater concentration on treatment efficiency of constructed wetland planted with mangrove species. Thesis. Chulalongkorn University, Thailand.

Naidoo, G. (2008). Differential effects of nitrogen and phosphorus enrichment on growth of dwarf Avicennia marina mangroves. Aquatic Botany, 2182, 1-7. http://dx.doi.org/10.1016/j.aquabot.2008.10.001

Nuengmatcha, P., \& Nuengmatcha, P. (2010). The efficiency of Avicennia marina to treat wastewater from shrimp farm effluent. The 36th Congress on Science and Technology of Thailand: Science and Technology for a Better Society, 100.

Reddy, K. R., \& D’ Angelo, E. M. (1997). Biochemical indicator to evaluate pollutant removal efficiency in constructed wetlands. Wat Sci. Tech., 35(5), 1-10. http://dx.doi.org/10.1016/S0273-1223(97)00046-2

Su, Y. M., Lin, Y. F., Jing, S. R., \& Lucy Hou, P. C. (2011). Plant growth and the performance of mangrove wetland microcosms for mariculture effluent depuration. Marin Pollution Bulletin, 62, 1455-1463. http://dx.doi.org/10.1016/j.marpolbul.2011.04.015

Vorakuldumrongchai, S. (1997). Influence of water and sediment from shrimp farms on structure and growth of mangrove forest at Kung Krabaen Bay, Chanthaburee Province. Thesis. Mahidol University, Thailand.

Wang, M., Zhang, J., Tu, Z., Gao, X., \& Wang, W. (2010). Maintenance of estuarine water quality by mangrove occurs during flood periods: A case study of a subtropical mangrove wetland. Marin Pollution Bulletin, 60, 2154-2160.

Wu, Y., Chung, A., Tam, N. F. Y., Pi, N., \& Wong, M. H. (2008). Constructed mangrove wetland as secondary treatment system for municipal wastewater. Ecological Engineering, 34, 137-146. http://dx.doi.org/10.1016/j.ecoleng.2008.07.010

Yang, Q., Tam, N. F. Y., Wong, Y. S., Luan, T. G., Su, W. S., Lan, C. Y., ... Cheung, S. G. (2008). Potential use of mangroves as constructed wetland for municipal sewage treatment in Futian, Shenzhen, China. Marin Pollution Bulletin, 57, 735-743. http://dx.doi.org/10.1016/j.marpolbul.2008.01.037

Zhang, J. E., Liu, J. L., Ouyang, Y., Liao, B. W., \& Zhao, B. L. (2010). Removal of nutrients and heavy metals from wastewater with mangrove Sonneratia apetala Buch-Ham. Ecological Engineering, 36, 807-812. http://dx.doi.org/10.1016/j.ecoleng.2010.02.008

Zhou, J. B., Jiang, M. M., Chen, B., \& Chen, G. O. (2009). Emergy evaluations for constructed wetland and conventional wastewater treatments. Communications in Nonlinear Science and Numerical Simulation, 14, 1781-1789. http://dx.doi.org/10.1016/j.ensns.2007.08.010 